\title{
HANNAH ARENDT - KANSALAISUUS JA KANSALLISUUS
}

Muistan yhden teach-in-tapahtuman, jossa Juha Sihvolan kanssa olimme molemmat estradilla. Se oli Heidi Hautala -teach-in Heidin ensimmäisen presidentinvaalikampanjan aikana marraskuussa 1999. Tuon tilaisuuden järjestäjä oli Tapani Hietaniemi, ja Juha puhui siinä kansalaisyhteiskunnasta. Itse puhuin Hannah Arendtista, erityisesti siitä miten Arendt sulkee väkivallan pois politiikan ajatuksesta ja miten politiikka on hänelle aina puhumisen aluetta. Jatkan nyt Arendtista ja lisään hänen välityksellään ajatuksen keskusteluun maailmankansalaisen isänmaasta. Arendtin näkökulmasta pyrin samalla polemisoimaan Juhan Maailmankansalaisen etiikkaa.

Isänmaa on outo käsite Hannah Arendtista puhuttaessa. Arendthan on Saksassa sekulaarina juutalaisena kasvanut nainen, jolle Saksa ja saksalainen kulttuuri olisi varmasti kiistattomasti ollut isänmaa - hänhän ihannoi nykyperspektiivistä katsoen kritiikittä eurooppalaista korkeakulttuuria - ellei tuo isänmaa olisi yllättäen merkinnyt häntä kansaan kuulumatomaksi ja halunnut sulkea häntä ulos. Kansalaisuus ei tuossa tilanteessa yhtäkkiä merkinnyt mitään kansallisuuden rinnalla.

Juha Sihvola kirjoittaa Maailmankansalaisen etiikka -kirjassa:

Ihmisen elämä voi olla onnellista vain, jos ihmisellä on oikeus perustaa paikallisen kokemuksen ja paikallisten olosuhteiden pohjalta yhteisöjä ja järjestää elämänsä niissä sellaiseksi kuin sen parhaaksi katsovat ilman, että ulkopuoliset asiaan puuttuvat. Valtiot, kansat, ja varsinkin kansallisvaltiot ovat kaikki tämän kulttuurisen omaleimaisuuden perinnäisiä ilmaisuja. (222).
Sihvola välttää ottamasta vahvasti kantaa kansallisvaltion ideaaliin ja huomauttaa kansallisvaltioiden historiallisesta harvinaisuudesta, mutta hän tuntuu silti pitävän kansallisvaltion ajatusta tärkeänä horisonttina. Meille Suomesta käsin kansallisuus (eli "paikallinen kokemus") ja poliittinen yhteisö (eli "elämänsä järjestäminen") näyttäytyvät helposti sellaisina, että niiden tulee langeta yhteen - "kansalaisuus" yhdistää jo sananakin meille syntyperän ja poliittisen yhteisön. (Pulkkinen 1999.)

Arendtille kansalaisuus ja kansallisuus erottuivat yllättäen: valtio, jonka kansalainen hän oli, lakkasi olemasta isänmaa, kun se yhtäkkiä ryhtyi kansallisvaltioksi. Arendtille ajatus kansallisvaltiosta oli aina vastenmielinen, hän ei myöskään koskaan kannattanut ajatusta Israelin valtiosta vain juutalaisen kansan valtiona. Yhdysvallat, joka oli hänen kotimaansa (en tiedä olisiko hän koskaan sanonut 'isänmaa') vuodesta 1941, oli hänelle monien kansakuntien poliittinen yhteisö, jonka liittovaltiomuotoa hän suositteli myös Eurooppaan kansallisvaltioiden sijaan.

Me katsomme asiaa helposti edellä mainitusta, Juhan kirjaamasta näkökulmasta, ja se vaikuttaa jopa neutraalilta ja universaalilta näkökulmalta: "Ihmisellä on oikeus perustaa paikallisen kokemuksen ja paikallisten olosuhteiden pohjalta yhteisöjä ja järjestää elämänsä niissä sellaiseksi kuin sen parhaaksi katsovat ilman, että ulkopuoliset asiaan puuttuvat." Mitä jos tämä ei olekaan yleinen näkökulma? Mitä jos näkökulman ottaisikin niistä käsin, jotka jo ovat liikkeellä - heitähän on tällä hetkellä yhä enemmän ja enemmän? Täytyisikö poliittinen yhteisö tällöin ajatella jotenkin 
muuten kuin Juhan puolustaman oikeuden pohjalta? Ehkä poliittista yhteisöä tulisikin sen sijaan hahmotella siten kuin Arendt ajatteli: Arendtille ihmiset tulevat poliittiseen yhteisöön yksilöinä, sen sijaan, että he olisivat osa sitä paikalliseen yhteisöön kuuluvina. Poliittinen yhteisö on hänen näkemyksensä mukaan keinotekoinen tila, jonka kansalaiset jakavat; sen ei tarvitse perustua mihinkään luonnolliseen kulttuuriseen yhteisöön. Arendt toisin sanoen erottaa vahvasti yhtältä kansalaisuuden ja toisaalta kansa-yhteisön jäsenyyden. Ehkä tämä erottelu voisi haastaa meitä ajatellessamme maailmankansalaisen isänmaata. (Arendt 2013.)

Kansalaisuuden ja kansan jäsenyyden erottaminen liittyy myös Juhan keskusteluissa usein esiin ottamaan kysymykseen siitä, onko Euroopan unioni askel kohti maailmankansalaisuutta vai ei. Useinhan on todettu, että Euroopan unioni on muodostettu monin tavoin maailmankansalaisuuden ihanteen vastaisesti: pikemminkin linnoitukseksi muuta maailmaa

KIRJALLISUUS

Arendt, Hannah (2013) Totalitarismin synty. Vastapaino. Tampere.

Pulkkinen, Tuija (1999) "Kielen ja mielen ykseys. 1800luvun suomalaisen nationalismin erityispiirteistä ja vastaan kuin maailmaa kohti avautuvaksi. Euroopan ulkorajat ovat koventuneet, ja jako niihin, jotka ovat sisällä ja niihin, jotka ovat ulkona, on entistä selvempi. Euroopan projekti onkin siis monessa suhteessa projekti muuta maailmaa vastaan tai vähintäänkin kilpailuasemassa muun maailman kanssa. Toisaalta jos katsotaan asiaa tässä hahmottelemastani kansojen ja kansalaisuuden perspektiivistä ja nimenomaan Euroopan ulkopuolelta tulevan EU-kansalaiseksi pyrkivän henkilön perspektiivistä, olisiko Euroopan unioni kuitenkin ajateltavissa kaikessa ulossulkevuudessaan myös jossakin mielessä helpommin lähestyttäväksi kuin kansallisuuden perustalle rakentuvat poliittiset yhteisöt? Jos haluat tulla poliittisen yhteisön jäseneksi, ehkä se käy hieman helpommin jos sinulta ei kansalaisuuden saavuttamiseksi vaadita minkään tietyn kansan jäsenyyttä. Ehkä tässä mielessä, ja vain tässä mielessä, Euroopan unionia voi siksi, että se ei ole kansallisvaltio, pitää pienenä askelena kohti maailmankansalaisuutta. Vai voiko?

\section{—TUIJA PULKKINEN}

perinnöstä poliittisessa ajattelussa”. Teoksessa Tuomas Lehtonen (toim.) Suomi. Outo pohjoinen maa? PSkustannus. Jyväskylä, 118-137.

Sihvola, Juha (2004) Maailmankansalaisen etiikka. Otava. Helsinki. 